\title{
Distribution of bacteria in the rumen contents of dairy cows given a diet supplemented with soya-bean oil
}

\author{
BY FRANÇOISE LEGAY-CARMIER AND D. BAUCHART* \\ Laboratorie d'étude du Métabolisme Energétique, INRA-CRZV, THEIX, \\ 63122 Ceyrat, France
}

(Received 22 March 1988 - Accepted 2 December 1988)

\begin{abstract}
1. Liquid-associated bacteria (LAB) were harvested from the liquid phase (LAB1) and from the solid phase of rumen contents after washing and manual shaking (LAB2). Solid-adherent bacteria (SAB) were recovered after washing and pummelling the total particles (SABI). The distribution and the chemical composition of these three bacterial compartments were investigated in four dairy cows fitted with rumen fistulas. The animals received successively a diet consisting of one part hay and one part barley-based concentrate (diet $\mathrm{C}$ ) and the same diet containing free soya-bean oil ( $79 \mathrm{~g} / \mathrm{kg}$ dry matter (DM); diet So).

2. The efficiency of removal of SAB 1 from total particles of rumen digesta collected $1 \mathrm{~h}$ after feeding, was calculated from the diaminopimelic acid content in particles and of the corresponding detached bacteria. It was $24 \%$ on diet $\mathrm{C}$ and $18 \%$ on diet So $(P<0.05)$, using a combination of homogenizing and 'stomaching' treatments in saline ( $9 \mathrm{~g}$ sodium chloride / 1 ) (reference treatment). For diets $\mathrm{C}$ and So respectively it was lowered by Tween in saline solution $(1 \mathrm{~g} / 1 ; 22.7$ and $17.8 \%$, not significant), but was increased when using a previous chilling $\left(6 \mathrm{~h}\right.$ at $\left.4^{\circ}\right)$ of homogenized particles before stomaching in saline $(28.8$ and $24.7 \%, P<0.05)$ and in Tween 80 in saline $(1 \mathrm{~g} / 1 ; 26.6$ and $20.8 \%, P<0.05)$.

3. The extent of removal of SABI from the solid fraction of rumen digesta by the reference treatment decreased with decreasing particle size; it was at the highest for particles retained on 4 and $2 \mathrm{~mm}$ sieves $(62 \cdot 1-82 \cdot 1 \%)$ and still elevated for particles retained on $0.8,0.4$ and $0.1 \mathrm{~mm}$ sieves $(41.3-57.9 \%)$. It was very much reduced for particles smaller than $0.1 \mathrm{~mm}(11.7-14.5 \%)$, suggesting the occurrence of favourable conditions for the adhesion of SAB firmly resistant to removal (SAB2).

4. The concentration of total SAB (SAB1 + SAB2) in particles collected $1 \mathrm{~h}$ after feeding was lower $(P<0.05)$ in diet $\mathrm{C}(190 \mathrm{~g} / \mathrm{kg} \mathrm{DM})$ than in diet So $(234 \mathrm{~g} / \mathrm{kg} \mathrm{DM})$. Values averaged 595-645 g/ $\mathrm{kg}$ DM for particles smaller than $0.1 \mathrm{~mm}$, but only 61 and $81-98 \mathrm{~g} / \mathrm{kg} \mathrm{DM}$ for particles retained on 4 and $0.4 \mathrm{~mm}$ sieves, and on a $0.1 \mathrm{~mm}$ sieve respectively. No significant differences were noted between diets but the effect of particle size was highly significant $(<0.1 \mathrm{~mm} v$. others $)$.

5. Postprandial variations of concentrations of total SAB on total particles exhibited a large increase $1 \mathrm{~h}$ after feeding in diet So $(P<0.05)$. Similar but amplified variations were observed for LAB in both diets $(P<0.05)$.

6. Total bacterial mass amounted to 213 and $231 \mathrm{~g} \mathrm{DM} / \mathrm{kg}$ whole-rumen contents DM in diets $\mathrm{C}$ and So respectively $6 \mathrm{~h}$ after feeding. Mean percentages of total SAB (69.8), LABl (7.3) and LAB2 (22.9) in total rumen contents were not significantly modified by the lipid level of the diet.
\end{abstract}

Bacteria of rumen contents may be considered to form a heterogeneous system divided into three major compartments, as proposed by Czerkawski (1986): compartment 1, corresponding to free-floating bacteria in the liquid phase (liquid-associated bacteria, LAB); compartment 2, corresponding to a mixture of LAB associated with the solid phase and bacteria loosely adherent to the solid phase (solid-adherent bacteria; SAB) that can be detached by washing; compartment 3 , corresponding to bacteria firmly adherent to the solid phase (SAB) that cannot be washed out.

During the last two decades, microbial synthesis in the rumen and the bacterial contribution to the nutrient flows at the duodenum have been calculated from marker ratios, as determined in purified LAB. However, recent investigations indicate that SAB are largely predominant in rumen contents (Forsberg \& Lam, 1975; Wolstrup \& Jensen, 1978; Cheng, quoted by Czerkawski, 1986; Craig et al. 1987a; Bauchart et al. 1989) and are probably present in the duodenal contents (Faichney, 1980), which implies that the marker ratios should be determined also on SAB.

\footnotetext{
* For reprints.
} 
It has been fully demonstrated that the distribution of bacterial species is different in the $\mathrm{SAB}$ and $\mathrm{LAB}$ fractions isolated from rumen contents (Minato et al. 1966) and that the chemical composition (Czerkawski, 1976; Merry \& McAllan, 1983; Bauchart et al. 1986) and the metabolic functions (Latham, 1980; Williams \& Strachan, 1984) of these two populations are very distinct. Moreover, the concentrations of SAB in feed particles appear to be controlled by the chemical composition of the diets. Thus, the attached population is increased by high levels of soluble carbohydrates which promote extracellular bacterial slime involved in the attachment of bacteria (Cheng et al. 1977). On the other hand, it is suggested that the attachment would be reduced by fat, which physically coats the particles (Devendra \& Lewis, 1974) and would also be responsible for the decrease in organic matter and cellulose digestion in the rumen. However, selective inhibition of microbial attack by triglycerides or free fatty acids, or both, might be more important than the coating of particles (Ørskov et al. 1978).

Difficulties experienced in detaching pure SAB samples from solid material in digesta account for the existence of numerous techniques of fractionation: physicochemical treatments using the properties of surfactants or salts in association with chilling or washing (Minato et al. 1966; Akin, 1980; Dehority \& Grubb, 1980; Craig et al. 1987a,b) as well as mechanical treatments such as homogenizing alone or in association with 'stomaching' (Mackie et al. 1983; Merry \& McAllan, 1983). However, the recovery of SAB obtained with these different extraction procedures has generally not been reported, which raises the question of the representativeness of those purified bacterial populations.

The objectives of the present study were to investigate the effects of adding a large amount of unprotected lipid (soya-bean oil) to the diet of dairy cows ( $79 \mathrm{~g}$ fatty acids $/ \mathrm{kg}$ dry matter (DM)) on the attachment of rumen bacteria to dietary particles. The initial step was to determine the efficiency of removal of SAB from rumen particles using a combination of an homoge nizing and stomaching treatment, and the effect of cooling or the addition of a surfactant (Tween 80 ) on this procedure. A further objective was to determine the extent of attachment of $\mathrm{SAB}$ in relation to particle size. Finally, the postprandial variations of the different bacterial compartments in rumen digesta were investigated.

Part of this work was presented at the $3^{\text {rd }}$ Annual meeting of the French National Institute of Agronomical Research (INRA) on feeding and nutrition of herbivores (Paris, March 1987) and was published as abstracts (Bauchart \& Legay-Carmier, 1988; LegayCarmier \& Bauchart, 1988).

\section{MATERIALS AND METHODS}

\section{Animals and diets}

Four lactating Friesian $\times$ Holstein cows were each fitted with a permanent cannula (internal diameter (i.d.) $110 \mathrm{~mm}$ ) in the dorsal sac of the rumen as described by Lefaivre $\&$ Fléchet (1983). Two diets, provided by the Dievet Society (27100 Le Vaudreuil, France) were used: a basal diet consisting, on a DM basis, of $500 \mathrm{~g}$ second-cut natural-grass hay and $500 \mathrm{~g}$ concentrate mix (diet $\mathrm{C}$ ) and the same diet supplying $79 \mathrm{~g}$ unprotected soya-bean oil $/ \mathrm{kg}$ diet (diet So) (Tables 1 and 2). This oil, stabilized by the addition of an antioxidant (butyl hydroxy-toluene; $1 \mathrm{~g} / \mathrm{kg} \mathrm{DM}$ concentrate), was introduced in the basal concentrate mix (Table 2) by impregnation on sugar-beet pulp.

DM allowances were calculated according to individual metabolizable energy (ME) requirements (INRA, 1978). DM intakes amounted to 12.7 and $14.1 \mathrm{~kg} / \mathrm{d}$ for diets $\mathrm{C}$ and So respectively. Diets $\mathrm{C}$ and So contained (/kg DM) 28.6 and $25.9 \mathrm{~g}$ nitrogen, 16.3 and $89 \cdot 5 \mathrm{~g}$ fatty acids, $11 \cdot 1$ and $12 \cdot 4 \mathrm{MJ} \mathrm{ME}$ respectively. Each diet was offered to two cows at 
Table 1. Mean dry matter (DM) and composition of the DM of the hay and of the basal concentrates of the control diet $(C)$ and of the experimental diet supplemented with unprotected soya-bean oil (So)

\begin{tabular}{lccc}
\hline \hline & Hay & Diet C & Diet So \\
\hline DM $(\mathrm{g} / \mathrm{kg}$ feed) & 850 & 919 & 938 \\
Composition of DM $(\mathrm{g} / \mathrm{kg}):$ & 908 & 899 & 901 \\
Organic matter & 18.935 & 17.390 & 20.400 \\
Gross energy $(\mathrm{MJ})$ & 0.84 & 0.99 & 1.24 \\
Net energy value* & 160 & 197 & 164 \\
Protein (nitrogen $\times 6.25)$ & 57 & 27 & 184 \\
Lipid & 16.9 & 15.6 & 162.1 \\
Fatty acid & 11.0 & 11.6 & 11.5 \\
Calcium & & & \\
\hline \hline
\end{tabular}

* Net energy value $=$ feed units for lactation (Vermorel, 1978).

Table 2. Composition of the basal concentrates in the control diet $(C)$ and experimental diet supp :mented with unprotected soya-bean oil (So) $(\mathrm{g} / \mathrm{kg}$ dry matter)

\begin{tabular}{lcc}
\hline & Diet C & Diet So \\
\hline Beet pulp & 457 & 375 \\
Barley & 228 & 188 \\
Uolasses & 29 & 30 \\
Soya-bean meal & 11 & 10 \\
Rapeseed meal & 118 & 98 \\
Soya-bean oil & 118 & 98 \\
Butyl hydroxytoluene & - & 158 \\
Calcium dichloride & - & 1 \\
Calcium hydrogen phosphate & $22 \cdot 1$ & $4 \cdot 0$ \\
Sodium chloride & $5 \cdot 1$ & $22 \cdot 1$ \\
Magnesium sulphate & $4 \cdot 3$ & $4 \cdot 1$ \\
Trace mineral mix* & $2 \cdot 4$ & $2 \cdot 4$ \\
Vitamin mix ${ }^{*}$ (mg) & $6 \cdot 3$ & $6 \cdot 3$ \\
\hline
\end{tabular}

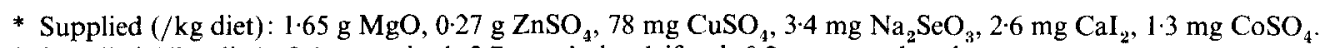

† Supplied (/kg diet): $3.4 \mathrm{mg}$ retinol, $2.7 \mathrm{mg}$ cholecalciferol, $0.2 \mathrm{mg}$ tocopherol.

a time, according to a replicated $2 \times 2$ Latin-square design. Each experimental period consisted of 3 weeks of adaptation followed by 2 weeks of measurement. Feed was given in two equal meals daily at 08.00 and 16.00 hours.

\section{Collection and treatments of digesta}

Trial 1. The first trial was designed to compare the effects of cooling or the addition of a detergent (Tween 80 ), or both, on the efficiency of removal of SAB from feed particles sampled from rumen contents. Representative samples ( $7 \mathrm{~kg}$ fresh material) of rumen digesta were collected at three depths using a sampling tube (i.d. $50 \mathrm{~mm}$, length $800 \mathrm{~mm}) 1 \mathrm{~h}$ after feeding, that is when bacterial contents were highest. The procedures for preparation and treatments of the liquid and solid phases and their associated bacteria are shown schematically in Figs. 1 and 2. Samples of rumen contents were squeezed through wire 


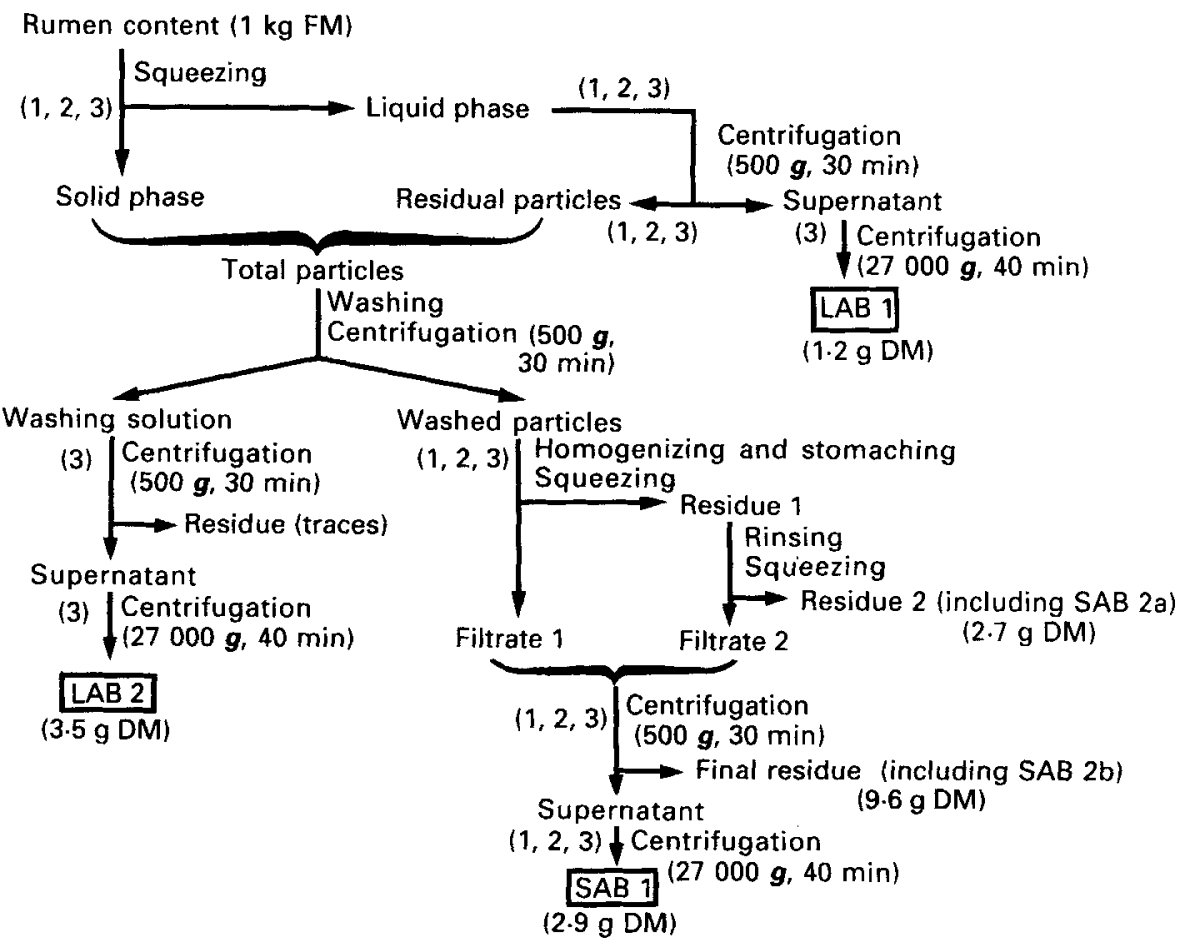

Fig. 1. Successive steps of the reference treatment used in the purification of solid-adherent bacteria (SAB1), of liquid-associated bacteria ( $L A B 1)$ and non- or loosely attached bacteria (LAB2) of the rumen contents. 1, 2, 3, steps used in trials 1,2 and 3 respectively. DM, dry matter; FM, fresh matter.

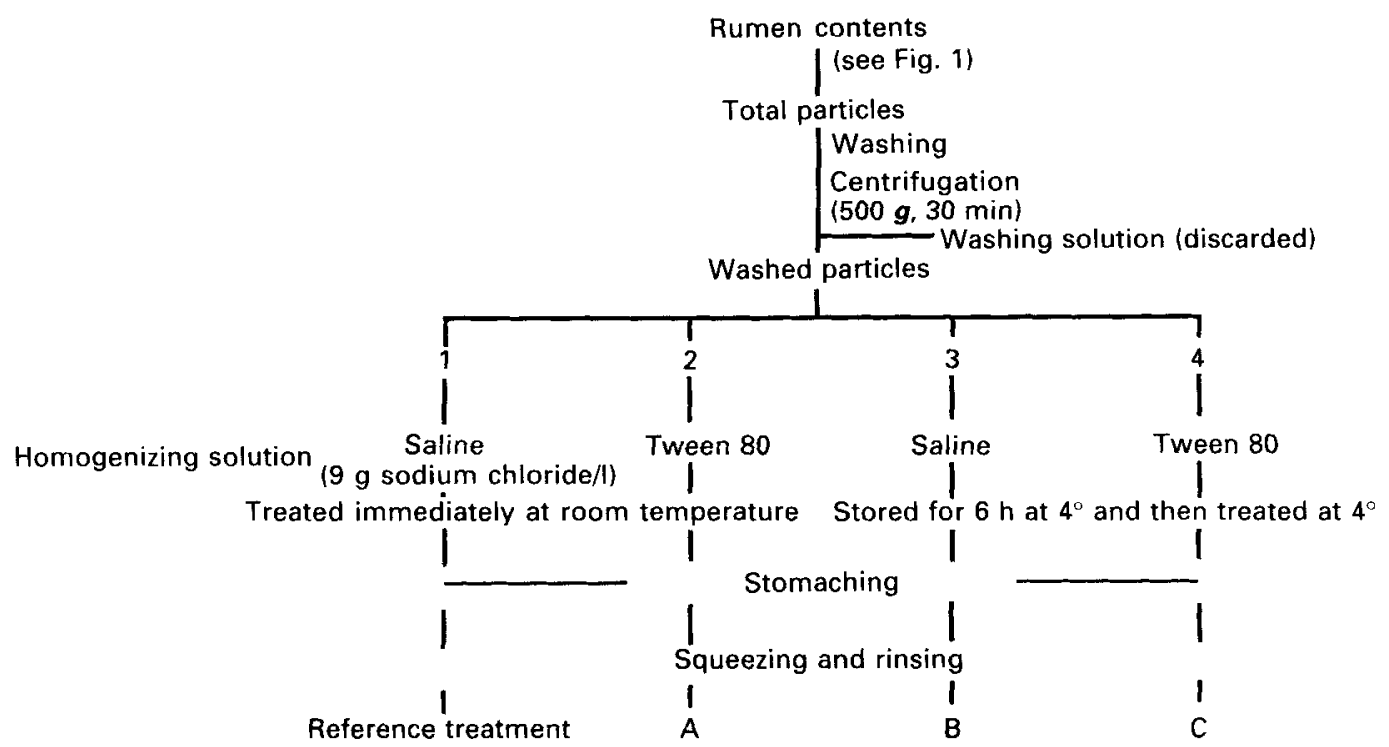

Fig. 2. Different treatments used in removing solid-adherent bacteria (SAB) from total washed food particles of rumen contents. For details of procedures, see p. 727. 
gauze $\left(1 \mathrm{~mm}\right.$ mesh). The liquid phase was centrifuged at $500 \mathrm{~g}$ for $30 \mathrm{~min}$ at $4^{\circ}$ (MSE Mistral 6 litres; rotor $6 \times 1$ litre) to isolate particles which were added to the solid material retained on the wire gauze, which constituted total particles of the rumen contents (Fig. 1).

Total particles were washed by manual shaking in a 1 litre bottle three times for $1 \mathrm{~min}$ in saline solution $(9 \mathrm{~g}$ sodium chloride $/ 1 ; 100 \mathrm{~g}$ fresh material/ $100 \mathrm{ml}$ ) to remove freefloating bacteria of the liquid phase associated with the particles (LAB2) and were then centrifuged at $500 \mathrm{~g}$ for $30 \mathrm{~min}$ at $4^{\circ}$. The washed particles were weighed and divided into four equal portions (subsamples 1-4) (Fig. 2).

$\mathrm{SAB}$ of the subsamples were harvested according to a method proposed by Merry \& McAllan (1983). Particles were suspended in saline (100 g washed particles/320 ml) and homogenized three times for $1 \mathrm{~min}$ using a Waring Blendor. The homogenate was pummelled for $5 \mathrm{~min}$ in a Colworth Stomacher 400 (A. J. Steward \& Co. Ltd, London) using sterile polyethylene bags $(180 \times 300 \mathrm{~mm})$ and squeezed through seven layers of surgical gauze. Solid residue was rinsed in saline $(100 \mathrm{~g} / 100 \mathrm{ml})$ and squeezed, as described previously, through surgical gauzes at the end of the procedure. Filtrates 1 and 2 (Fig. 1 ) were pooled and centrifuged at $500 \mathrm{~g}$ for $30 \mathrm{~min}$. The supernatant fraction was centrifuged at $27000 \mathrm{~g}$ for $40 \mathrm{~min}$ at $4^{\circ}$ (Kontron $\mathrm{H} 401$; rotor $\mathrm{A} 6.146 \times 250 \mathrm{ml}$ ) for isolation of SAB1 which were freeze-dried and weighed (Fig. 1).

Treatments of the four subsamples differed in respect of the temperature conditions and the composition of the solution used in the homogenization of particles (Fig. 2). Subsamples 1 and 2 were homogenized and treated without delay at room temperature, and subsamples 3 and 4 were homogenized and then stored at $4^{\circ}$ for $6 \mathrm{~h}$ before subsequent treatments. Subsamples 1 and 3 were homogenized in saline and subsamples 2 and 4 in a solution of Tween 80 in saline $(1 \mathrm{~g} / 1)$.

SAB concentrations and the efficiency of detachment of these bacteria from particles were determined from diaminopimelic acid (DAPA; see p. 730) concentrations in total washed particles before and after homogenizing and stomaching, and in the removed bacteria, assuming that this population (SAB1) was representative of that in the particles $(\mathrm{SAB} 1+\mathrm{SAB} 2)$.

Trial 2. The objectives of this part of the study were to compare the concentrations of $\mathrm{SAB}$ and the efficiency of detachment from rumen particles of different sizes. From $1 \mathrm{~kg}$ fresh rumen contents collected $1 \mathrm{~h}$ after feeding, total particles (including residual particles) were prepared according to the procedure described in trial 1 (Fig. 1). Particles $(50 \mathrm{~g})$ were separated by size by wet sieving for $5 \mathrm{~min}$ according to Grenet (1966), using saline as the washing solution. Sieve sizes (corresponding to mesh size) were successively 4 , $2,0.8,0.4$ and $0.1 \mathrm{~mm}$. Particles smaller than $0.1 \mathrm{~mm}$, suspended in the effluent solution (effluent particles; EP), were isolated by centrifugation at $500 \mathrm{~g}$ for $30 \mathrm{~min}$, and the supernatant fraction containing free-floating bacteria was discarded. SAB were detached from the different classes of particles (including $\mathrm{EP} ;<0.1 \mathrm{~mm}$ ) according to the reference treatment used in trial 1 (Fig. 1).

Particle distribution was determined by weighing after drying at $80^{\circ}$ for $48 \mathrm{~h}$. Calculations of the SAB concentrations and efficiency of detachment of these bacteria from each class of particles were the same as in trial 1.

Trial 3. Postprandial variations in SAB and LAB in rumen contents were determined during a $6 \mathrm{~h}$ period starting from the initiation of feeding.

Rumen contents were sampled (1200 g fresh material) as described for trial 1 , just before feeding and $0.5,1.5,2 \cdot 0,4.0$ and $6.0 \mathrm{~h}$ after feeding. They were fractionated into solid and liquid phases by squeezing, and weighed. Residual particles of the liquid phase, isolated as in trial 2, were added to the solid phase and washed in saline to remove LAB2 (Fig. 1). 
$\mathrm{LAB} 1$ and $\mathrm{LAB} 2$ were estimated by weighing after centrifugations at $500 \mathrm{~g}$ for $30 \mathrm{~min}$ and $27000 \mathrm{~g}$ for $40 \mathrm{~min}$, as described in Fig. 1; bacteria were washed with distilled water and freeze-dried. The SAB concentrations in the washed particles were determined in terms of DAPA.

At the end of each experimental period, the rumen was emptied manually $6 \mathrm{~h}$ after feeding to determine the partition of bacteria in the different compartments of rumen contents. Different parts of the rumen contents were weighed and sampled by preparing representative portions which corresponded to $0.5 \%$ of each part of the rumen contents. Solid and liquid phases were then separated by squeezing in order to determine their respective proportions in the whole rumen contents. The concentrations of total SAB were calculated from DAPA concentrations in total washed particles as described for trial 1, and the concentrations of $\mathrm{LAB} 1$ and $\mathrm{LAB} 2$ were determined by weighing after centrifugations as described previously for trial 3 .

\section{Chemical analysis}

The DM content of food particles and bacteria was determined by drying at $80^{\circ}$ for $2 \mathrm{~d}$. Freeze-dried samples of feed particles and bacteria were analysed for RNA by purine measurement according to the method of Zinn \& Owens (1986), as modified by Ushida et al. (1985), and for total $\mathrm{N}$ using the macro-Kjeldahl method (Association of Official Analytical Chemists, 1980). DAPA content was determined according to the method of Mason \& Bech-Andersen (1975), modified by Colombier (1981). Freeze-dried samples of bacteria $(200 \mathrm{mg})$ and total particles $(400 \mathrm{mg}$ ) were hydrolysed with $5.5 \mathrm{M}$-hydrochloric acid by refluxing at $120^{\circ}$ for $24 \mathrm{~h}$. The cooled hydrolysate was filtered first on a glass-sintered funnel (no. 4) and then on micropore $(0.1 \mu \mathrm{m})$. Amino acids were separated by liquid chromatography using a $600 \mathrm{~mm}$ column (i.d. $6 \mathrm{~mm}$ ) packed with Dowex $50 \mathrm{w} \times 8$ (100-200 mesh). A gradient buffer system consisting of $0 \cdot 2$ M-sodium citrate, $\mathrm{pH} 3 \cdot 2$, and $0.25 \mathrm{M}$-sodium citrate, $\mathrm{pH} 4 \cdot 2$, was used. Detection of DAPA was achieved at $420 \mathrm{~nm}$ using acid ninhydrin reagent.

The total lipids were extracted in chloroform-methanol (2:1, by vol.; Folch et al. 1957) and then in hexane-ethanol-HCl $(25: 10: 10$ by vol.; Bauchart et al. 1984) and weighed. Total fatty acid content was determined by gas-liquid chromatography using heptadecanoic acid (C17:0) as an internal standard (Bauchart et al. 1987).

Statistical validity of the differences between means was calculated using the $U$ test (nonparametric method) of Mann \& Whitney (1947). The chemical composition of rumen bacteria was compared by two-way analysis of variance with diet and sample as the independant variables.

\section{RESULTS}

Chemical composition of $S A B 1, L A B 1$ and $L A B 2$

The chemical composition of purified SAB (SAB1), LAB1 and LAB2 of rumen contents collected in equal amounts $0,2,4$ and $6 \mathrm{~h}$ after feeding and treated as described for trial 3 , is reported in Table 3 .

Marked differences between treatments for different constituents were observed for SAB1 on the one hand and LAB1 and LAB2 on the other hand for both diets C and So. Total DAPA, RNA and ash concentrations of SAB1 were lower than those of LABI and LAB2, and total lipids and fatty acids were twice as high $(P<0.01)$ in SAB1 as in LAB1 and LAB2.

The two-way analysis of variance showed that addition of unprotected soya-bean oil in the diet led to a large increase in total lipid and fatty acid contents $(P<0.01)$ in the three bacterial populations (SAB1, LAB1 and LAB2). 
Bacteria in rumen contents of dairy cows

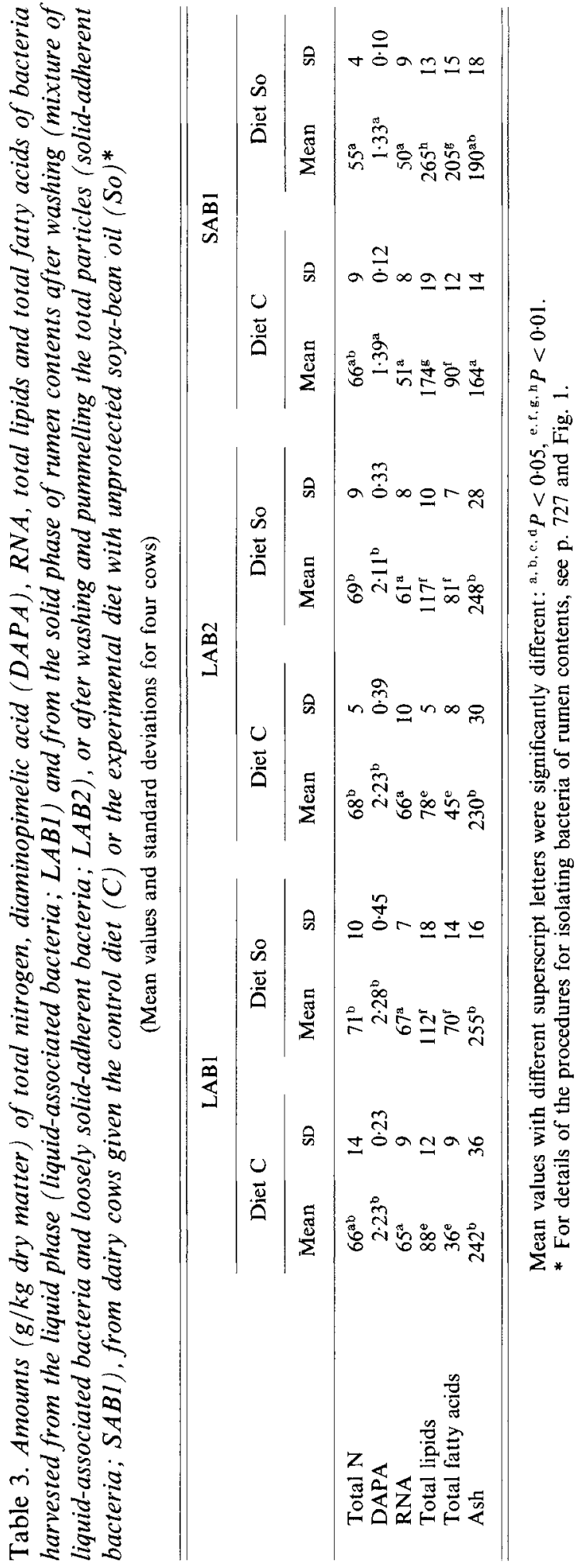


Table 4. Trial 1. Efficiency of removal of bacteria from the solid phase after washing and pummelling the total particles (SAB1) from washed rumen contents using three experimental treatments ( $A, B, C$ ) compared with values obtained by the reference procedure (see Fig. 2) in four dairy cows given the control diet $(C)$ or the experimental diet with unprotected soya-bean oil ( $S o)$

(Mean values and standard deviations for four cows)

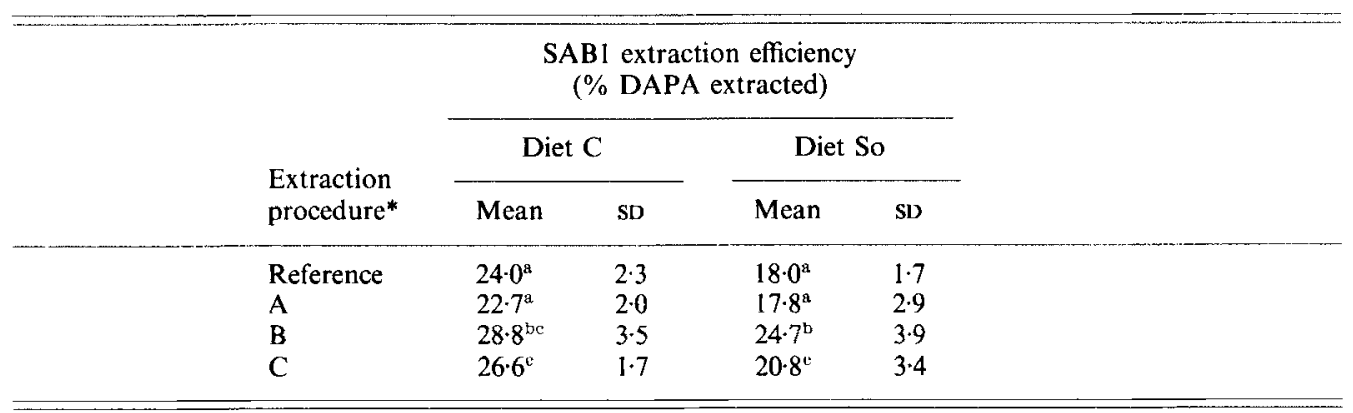

DAPA, diaminopimelic acid.

* A, Tween $80 ; \mathrm{B}$, stored at $4^{\circ}$ for $6 \mathrm{~h} ; \mathrm{C}$, stored at $4^{\circ}$ and treated with Tween 80 ; for details of procedures, see p. 727.

Mean values with different superscript letters were significantly different: ${ }^{\mathbf{a}, \mathbf{b}, \mathbf{c}} \boldsymbol{P}<0.05$.

Calculations of SAB concentrations in feed particles and their efficiency of detachment were done in the three trials from DAPA measurements. DAPA concentrations in purified extracted SAB were not significantly altered by the lipid content of the diets (Table 3 ), the different treatment conditions to detach bacteria (trial 1), the particle size (trial 2) or the postprandial time of collection of rumen digesta (trial 3). A mean value of 1.36 (SD 0.12) g DAPA $/ \mathrm{kg}$ SAB DM was thus used for all subsequent calculations in three trials.

Trial 1. Mean total SAB concentrations were 190 and $234 \mathrm{~g} / \mathrm{kg} \mathrm{DM}$ of total rumen particles collected $1 \mathrm{~h}$ after feeding with diets $\mathrm{C}$ and So respectively. The efficiency of SAB detachment, using the reference treatment combining homogenizing and pummelling in saline at room temperature was 24.0 and $18.0 \%$ with diets $C$ and So respectively $(P<0.05)$.

Treatments that used a saline solution containing Tween $80(\mathrm{~g} / 1)$ at room temperature (A) or saline at $4^{\circ}$ (B) displayed opposite effects on the detachment of SAB compared with the reference treatment (Table 4).

The high lipid content of diet So increased the positive effects of cooling on the efficiency of SAB detachment with treatment $B(P<0.05)$ and treatment $C$ (stored at $4^{\circ}$, then saline with Tween $80(1 \mathrm{~g} / 1)$ ) (not significant) and limited the negative effects of Tween 80 with treatment A (not significant).

Trial 2. The size distribution of feed particles in rumen contents collected $1 \mathrm{~h}$ after feeding is given in Table 5. The major classes of particles were those retained on 4 and $0.1 \mathrm{~mm}$ sieves $(20.0-22.6 \%$ of total particles DM) and the particles smaller than $0.1 \mathrm{~mm}$ $(24.0 \%$ diet C, $29.8 \%$ diet So) with both diets. No significant differences in the size distribution of particles were observed between diets. DAPA concentrations averaged, for both diets, $0.074,0.093$ and $0.120 \mathrm{~g} / \mathrm{kg} \mathrm{DM}$ of particles retained on 4 and $2 \mathrm{~mm}, 0.8$ and $0.4 \mathrm{~mm}$, and $0.1 \mathrm{~mm}$ sieves respectively. For particles smaller than $0.1 \mathrm{~mm}(\mathrm{EP})$, values were much greater than for particles held on the $0.1 \mathrm{~mm}$ sieve. Addition of soya-bean oil led to an $18.8 \%$ increase $(P<0.05)$ in DAPA concentrations in EP. Calculations of 


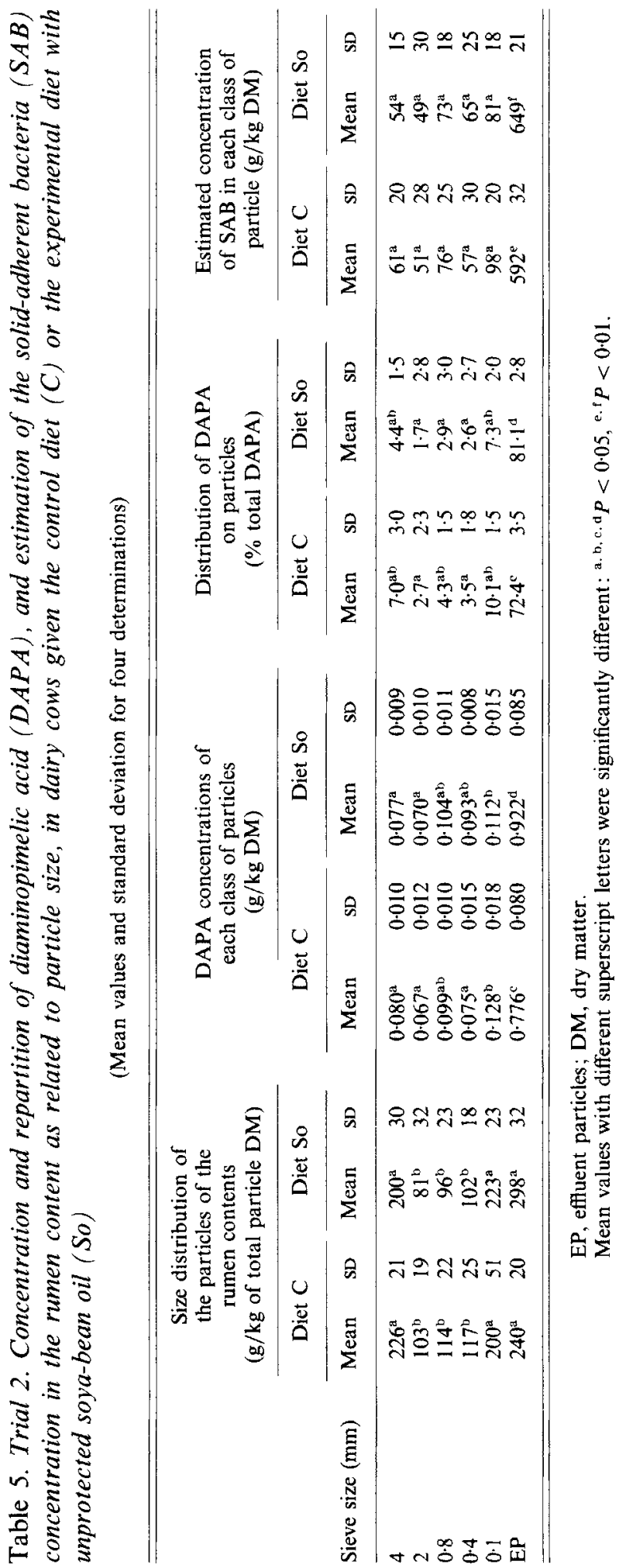


Table 6. Trial 2. Percentage of solid adherent bacteria ( $S A B 1)^{*}$ recovered from particles of different sizes as calculated from diaminopimelic acid (DAPA) concentrations in particles before and after treatment in four dairy cows given the control diet (C) or the experimental diet with unprotected soya-bean oil (So)

(Mean values and standard deviations for four determinations)

\begin{tabular}{|c|c|c|c|c|}
\hline \multirow{3}{*}{$\begin{array}{l}\text { Sieve size } \\
\quad(\mathrm{mm})\end{array}$} & \multicolumn{4}{|c|}{ Relative SAB extraction rate } \\
\hline & \multicolumn{2}{|c|}{ Diet C } & \multicolumn{2}{|c|}{ Diet So } \\
\hline & Mean & SD & Mean & $\mathrm{SD}$ \\
\hline 4 & $82 \cdot 1^{\mathrm{a}}$ & $8 \cdot 3$ & $74 \cdot 2^{\mathrm{a}}$ & $10 \cdot 7$ \\
\hline 2 & $78 \cdot 4^{\mathrm{a}}$ & $8 \cdot 1$ & $62 \cdot 1^{\mathrm{ab}}$ & $10 \cdot 3$ \\
\hline $0 \cdot 8$ & $51 \cdot 4^{b}$ & $11 \cdot 4$ & $57 \cdot 9^{\mathrm{b}}$ & $6 \cdot 6$ \\
\hline $0 \cdot 4$ & $55 \cdot 0^{\mathrm{b}}$ & $6 \cdot 7$ & $48 \cdot 5^{\mathrm{b}}$ & $7 \cdot 8$ \\
\hline $0-1$ & $41 \cdot 3^{b}$ & $12 \cdot 1$ & $53 \cdot 8^{\mathrm{b}}$ & $6 \cdot 1$ \\
\hline $\mathrm{EP}$ & $14.5^{\circ}$ & $3 \cdot 1$ & $11 \cdot 7^{c}$ & $3 \cdot 7$ \\
\hline
\end{tabular}

EP, effluent particles.

Mean values with different superscript letters were significantly different: ${ }^{\mathrm{a}, \mathrm{b}} P<0.05, " P<0.01$.

* For details of procedures, see p. 729 and Fig. 2.
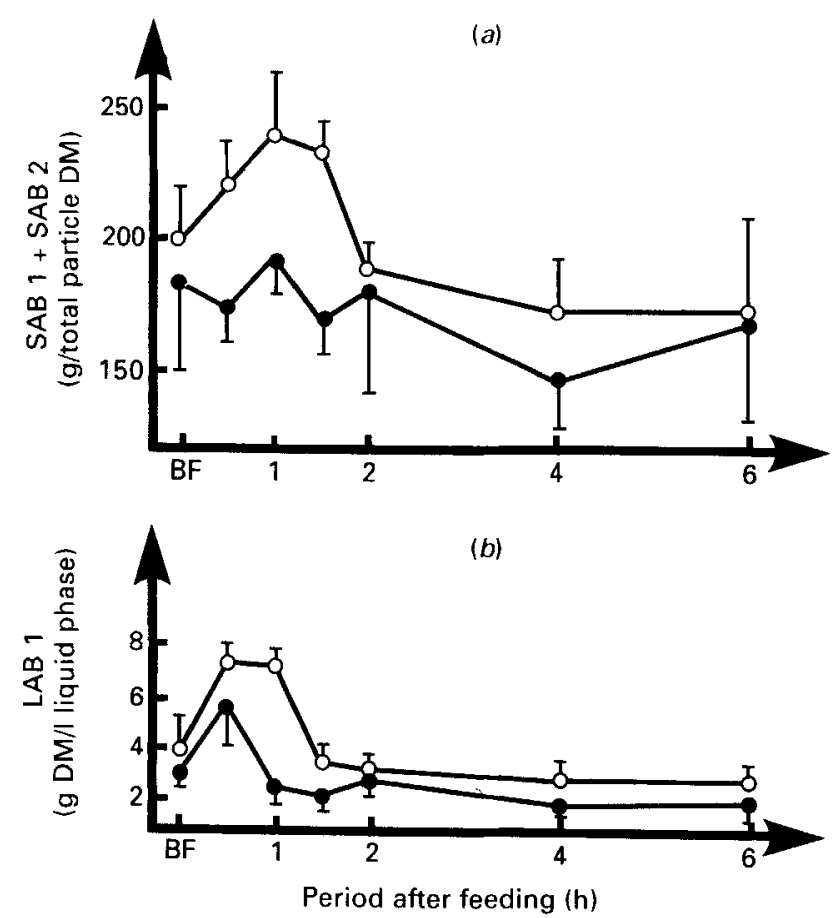

Fig. 3. Postprandial variations in (a) solid-adherent bacteria of total particles (SABI + SAB2; g/kg total particle dry matter (DM)) and $(b)$ of liquid-associated bacteria in the liquid phase (LAB1; g DM/1) in the rumen contents of four dairy cows fed on the control diet $(O)$ or the experimental diet supplemented with unprotected soya-bean oil $(\mathrm{O})$. BF, just before feeding. Points are mean values, and standard deviations represented by vertical bars. 
DAPA distribution in particles (Table 5) showed the importance of particles smaller than $0.1 \mathrm{~mm}(72.4$ and $81.1 \%$ of total DAPA for diets $\mathrm{C}$ and So respectively).

The mean SAB concentrations amounted to $61 \mathrm{~g} / \mathrm{kg}$ DM of particles held on sieves with a mesh size greater than $0.4 \mathrm{~mm}$ for both diets (Table 5), and the estimated concentrations of SAB were higher for particles held on the $0.1 \mathrm{~mm}$ sieve $(90 \mathrm{~g} / \mathrm{kg} \mathrm{DM})$ and for particles smaller than $0.1 \mathrm{~mm}(620 \mathrm{~g} / \mathrm{kg} \mathrm{DM} ; P<0 \cdot 01)$.

The efficiency of SAB1 detachment decreased with particle size (Table 6). It was highest for particles held on the $4 \mathrm{~mm}$ sieve $(82.1 \%$ diet C, $74.2 \%$ diet So) and was lowest for particles smaller than $0.1 \mathrm{~mm}(14.5 \% \operatorname{diet} \mathrm{C}, 11.7 \% \operatorname{diet}$ So, $P<0.01)$.

Trial 3. The changes in the concentrations of total SAB in total particles in the rumen contents just before feeding and $0 \cdot 5,1,1 \cdot 5,2,4$ and $6 \mathrm{~h}$ after feeding are shown in Fig. 3. For diet So, the concentrations of SAB significantly increased between 0 and $1 \mathrm{~h}$, and then significantly decreased between 1 and $2 \mathrm{~h}$. In the same way, similar postprandial changes in the concentrations of LAB in the liquid phase of the rumen contents are shown in Fig. 3.

SAB and LAB concentrations in samples taken $2-6 \mathrm{~h}$ after feeding had similar values to those before feeding irrespective of the diet.

The importance of the three bacterial compartments (total SAB, LAB1, LAB2) in total rumen contents was determined quantitatively after complete rumen emptying, $6 \mathrm{~h}$ after initiation of feeding. Mean total rumen contents were 82 and $79 \mathrm{~kg}$ fresh material (FM) and consisted of 418 and $387 \mathrm{~g}$ of total particles (214 and $236 \mathrm{~g} / \mathrm{kg} \mathrm{DM}) / \mathrm{kg}$ FM and 582 and $613 \mathrm{~g}$ of liquid phase (16 and $18 \mathrm{~g} / \mathrm{kg} \mathrm{DM}$ ) (without residual particles) $/ \mathrm{kg} \mathrm{FM}$ for diets C and So respectively.

Total bacterial mass in the total rumen contents was estimated (see trial 3) from representative portions collected in different parts of the rumen (Table 7). It averaged $1722 \mathrm{~g} \mathrm{DM}$ for diet $\mathrm{C}$ and $1871 \mathrm{~g} \mathrm{DM}$ for diet So (not significant). Total SAB represented (\% of the total bacterial mass) 72.5 and $67 \cdot 1$, LAB1 6.6 and 8.0 and LAB2 20.9 and 24.9 for diets $\mathrm{C}$ and So respectively (Table 7 ).

\section{DISCUSSION}

Successive treatments of rumen contents by straining the fresh material and by washing, homogenizing and pummelling the particles, facilitated the isolation and characterization of distinct bacterial populations. Chemically, SAB and LAB were clearly different, as previously observed by Merry \& McAllan (1983) and Bauchart et al. (1986). In earlier work, Williams \& Strachan (1984) reported a definite difference in the function of these two bacterial populations, the enzymes degrading plant cell-wall polysaccharides being more active in the SAB, and the non-structural soluble saccharides being metabolized more by the LAB.

On the other hand, the chemical composition of LAB2 was quite similar to that of LAB1, which indicated that there may not be a specific population of bacteria loosely attached to feed particles. However, it is possible that these two populations of LAB have some distinct metabolic functions, as shown by Williams \& Strachan (1984), for enzyme degradation of polysaccharides. Compared with LAB, the lower RNA:N and DAP:N exhibited by SAB isolated from dairy cows (present experiment; Craig et al. 1987b), or steers (Merry \& McAllan, 1983) offered diets containing 350-500 g concentrate $/ \mathrm{kg}$, might stem from a lower growth rate of this population. This could result from a high density of SAB in feed particles, which would limit the utilization of substrates by these bacteria either by a poor diffusion to the centre of the colony (Bates et al. 1985) or by enzyme repression (McLoughlin, 1983). Nevertheless, this poor net growth rate would probably be associated with a different turn-over rate of bacteria in the solid (Czerkawski, 1986). 


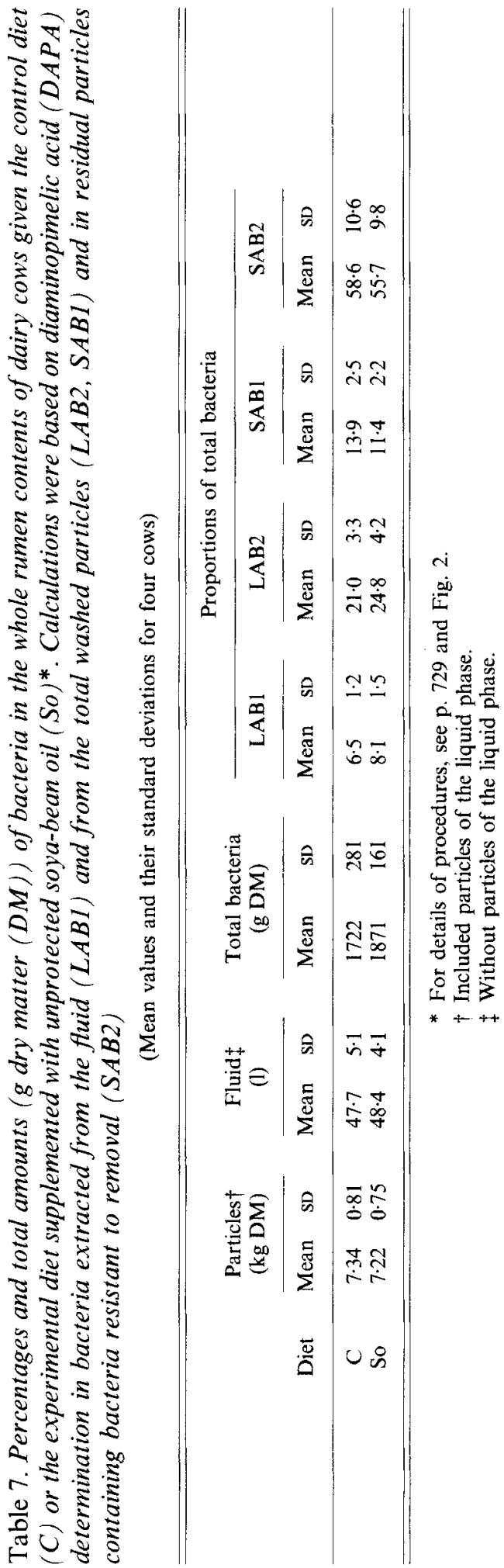


Large amounts of lipids in SAB were likely to be due to high concentrations of lipids in particles and of microbial lipid precursors (fatty acids, acetate) in the immediate surroundings of those particles. In the same way, the fatty acid concentration which was three times higher in SAB than in LAB with the soya-bean oil diet, might have been the outcome of the preferential adsorption of dietary fatty acids onto feed particles and bacterial cells (Harfoot, 1981), or of lipolysis.

In trial 1 , homogenizing and stomaching rumen particles at $4^{\circ}$ proved to be a more effective method of releasing SAB. The positive effect of chilling, previously observed by several authors (Minato et al. 1966; Minato \& Suto, 1978, Dehority \& Grubb, 1980), probably arises from breaking the attachment structure of bacteria (Dehority \& Grubb, 1980 ). On the other hand, the lowered removal rate of SAB with Tween 80 could be the result of the partial denaturation or lysis of different rumen species such as Bacteroides succinogenes, Ruminococcus albus and $R$. flavefaciens (Minato \& Suto, 1978), which represent the largest part of the bacterial population in feed particles in rumen contents. Since SAB removal was calculated from DAPA in particles before and after treatment, it must be supposed that DAPA associated with bacterial membranes still remains on feed particles when the cells are lysed. The reduction in feed-particle size seemed to increase the amounts of SAB attached. In support of these results, organic matter degradation was shown to be inversely related to particle size as noted in sheep offered rye grass (Defaalla \& Kay, 1980) and in cattle offered linseed meal (Ehle et al. 1982) or soya-bean (Weakley, quoted by Ehle et al. 1982) basal diets. Latham (1980) emphasized that bacterial adhesion is strongly stimulated by deep-seated cell wall components exposed in damaged areas on plant fragments. The elevated concentration of SAB on the smallest particles of rumen contents could be explained initially by the high frequency of damage sites on these fine particles. Additionally, Cheng et al. (1977) observed that bacteria attached to fine particles are surrounded by larger quantities of intercellular fibrous carbohydrate slime than when they are attached to larger particles. Cheng et al. (1977) showed that the bacterial production of slime, which mediates the attachment of the bacterium to the plant surface, is stimulated by the increased availability of soluble carbohydrates, mainly provided by the fine particles of the concentrate. Such factors might strengthen the adhesion of SAB onto small particles, and explain the low removal rate of $\mathrm{SAB}$ from these particles, as measured in our experiment. It is mainly these small particles, with their previously mentioned characteristics, that limited the extraction of SAB from total particles to $29.0 \%$, as measured in dairy cows $(32 \%$; Craig et al. $1987 a)$ and in sheep (40\%; C. Poncet, personnal communication).

In the present experiment, the high level of polyunsaturated fatty acids (PUFA) in diet So did not decrease SAB concentration in feed particles, in fact a slight increase was observed. In the same way, organic matter digestion in the rumen was not significantly modified: $45.5 \%$ (SD 2.4) diet C, 43.0\% (SD 1.5) diet So (M. Doreau and D. Bauchart, unpublished results). The increase in $\mathrm{SAB}$ associated with the solid in diet So was probably not due to a reduction in the predatory capacity of protozoa for bacteria, since we have shown that soya-bean oil did not modify significantly the number of protozoa in the rumen fluid of the cows (Bauchart et al. 1989), although they may have affected those in the solid. Large amounts of calcium $(11.2 \mathrm{~g} / \mathrm{kg} \mathrm{DM})$ were included in both diets, which could explain the absence of negative effects of PUFA on SAB concentration and on rumen digestion of organic matter. Lipid supplementation of the diet usually leads to a net reduction in organic matter digestion in the rumen, especially with PUFA of fats such as soya-bean oil (McLeod \& Buchanan-Smith, 1972) or linseed oil (Sutton et al. 1983). In vitro, PUFA inhibit the growth of cellulolytic (Maczulack et al. 1981) and methanogenic (Henderson, 1973) rumen bacteria by reducing the availability of divalent cations by forming soaps (Bryant et al. 1959). 
In other respects, $\mathrm{Ca}$ intake being similar for both diets, the increase in the concentration of SAB in total particles with diet So must be related to the presence of soya-bean oil only. Several explanations are possible. First, preferential adsorption of dietary lipids on particles could enhance $\mathrm{Ca}$ concentration at this site and, thereby, stimulate the fixation of SAB by electrostatic attraction (Costerton et al. 1978; Latham, 1980). Second, the intensive uptake of fatty acids by SAB with diet So, as described previously, could spare the energy expenditure required for the de novo synthesis of fatty acids by bacterial cells and, indirectly, stimulate production of slime. The latter is known to be under nutritional control (Berg et al. 1972; Cheng et al. 1977).

The increase in the concentration of SAB and LAB just after feeding was probably due to a stimulation of bacterial growth, as previously described for LAB in cattle (Coto et al. 1983). This bacterial growth needs large amounts of ATP (Bergen, 1979) produced from dietary substrates. This effect was more marked with the soya-bean oil diet, and might have the same origin as the increase in slime production with this diet.

The authors thank Dr M. Doreau and Mr A. Ollier and their staff for the provision and maintenance of the animals and Dr J. P. Jouany for DAPA measurements. They would also like to thank Mrs C. Legay and Mrs M. Martinaud for skilled assistance.

\section{REFERENCES}

Akin, D. E. (1980). Evaluation by electron microscopy and anaerobic culture of types of rumen bacteria associated with digestion of forage cell walls. Applied and Environmental Microbiology 39, 242-252.

Association of Official Analytical Chemists (1980). Official Methods of Analysis, 13th ed., pp. 127-129. Washington DC: Association of Official Analytical Chemists.

Bates, D. B., Gillett, J. A., Barao, S. A. \& Bergen, W. G. (1985). The effect of specific growth rate and stage of growth on nucleic acid-protein values of pure cultures and mixed ruminal bacteria. Journal of Animal Science 61, 713-724.

Bauchart, D., Doreau, M. \& Kindler, A. (1987). Effect of fat and lactose supplementation on digestion in dairy cows. 2. Long-chain fatty acids. Journal of Dairy Science 70,71-80.

Bauchart, D. \& Legay-Carmier, F. (1988). Effets de la prise du repas et de la teneur en lipides du régime sur la quantité de bactéries libres et liées aux particules du contenu de rumen chez la vache laitière. Reproduction, Nutrition, Développement 28, 139-140.

Bauchart, D., Legay-Carmier, F., Doreau, M. \& Jouany, J. P. (1986). Effets de l'addition de matières grasses non protégées à la ration de la vache laitière sur la concentration et la composition chimique des bactéries et des protozoaires. Reproduction, Nutrition, Développement 26, 309-310.

Bauchart, D., Legay-Carmier, F., Jouany, J. P., Michalet-Doreau, B. \& Doreau, M. (1989). Effects de l'addition de palmitostéarine ou d'huile de soja sur les protozoaires du rumen chez la vache laitière et chez la mouton. Reproduction, Nutrition, Développement 29 (In the press).

Bauchart, D., Vérité, R. \& Rémond, B. (1984). Long-chain fatty acid digestion in lactating cows fed fresh grass from spring to autumn. Canadian Journal of Animal Science 64, Suppl., 330 331.

Berg, B., Hofsten, B. V. \& Pettersson, G. (1972). Electromicroscopic observation on the degradation of cellulose fibres by Cellvibrio fulcus and Sporocytophaga myxococcoides. Journal of Applied Bacteriology 35, 215-219.

Bergen, W. G. (1979). Factors affecting growth yields of micro-organisms in the rumen. Tropical Animal Production 4, 13-20.

Bryant, M. P., Robinson, I. M. \& Chu, H. (1959). Observations on the nutrition of Bacteroides succinogenes - a ruminal cellulolytic bacteria. Journal of Dairy Science 42, 1831-1847.

Cheng, K.J., Akin, D. E. \& Costerton, J. W. (1977). Rumen bacteria: interaction with particulate dietary components and response to dietary variations. Federation Proceedings 36, 193-197.

Colombier, J. (1981). Contribution à l'étude du rôle des protozoaires ciliés du rumen dans l'apport d'azote microbien dans le duodénum du ruminant. Thèse de Docteur-Ingénieur, Université de Clermont II.

Costerton, J. W., Geesey, G. G. \& Cheng, K. J. (1978). How bacteria stick. Scientific American 238, 86-95.

Coto, G., Geerken, C. M. \& Cruz, R. (1983). Rate of microbial mass synthesis in the rumen in vitro using coast cross I Bermuda grass. Cuban Journal of Agricultural Science 17, 275-284.

Craig, W. M., Broderick, G. A. \& Ricker, D. B. (1987a). Quantitation of microorganisms associated with the particulate phase of ruminal ingesta. Journal of Nutrition $117,56-62$

Craig, W. M., Brown, D. R., Broderick, G. A. \& Ricker, D. B. (1987 b) Post-prandial compositional changes of fuid and particle-associated ruminal micro-organisms. Journal of Animal Science 65, 1042-1048. 
Czerkawski, J. W. (1976). Chemical composition of microbial matter in the rumen. Journal of the Science of Food and Agriculture 27, 621-632.

Czerkawski, J. W. (1986). Degradation of solid feeds in the rumen: spatial distribution of microbial activity and its consequences. In Control of Digestion and Metabolism in Ruminants. Proceedings of the Sixth International Symposium on Ruminant Physiology, Banff, Canada, pp. 158-172 [L. P. Milligan, W. L. Grovum and A. Dobson, editors]. Englewood Cliffs, New Jersey: Prentice Hall.

Dafaalla, B. F. M. \& Kay, R. N. B. (1980). Effect of hay particle size on retention time, dry matter digestibility and rumen $\mathrm{pH}$ in sheep. Proceedings of the Nutrition Society 39, $71 \mathrm{~A}$.

Dehority, B. A. \& Grubb, J. A. (1980). Effect of short-term chilling of rumen contents on viable bacterial numbers. Applied and Environmental Microbiology 39, 376-381.

Devendra, C. \& Lewis, D. (1974). The interaction between dietary lipids and fibre in the rumen. Animal Production $19,67-76$

Ehle, F. R., Murphy, M. R. \& Clark, J. H. (1982). In situ particle size reduction and the effect of particle size on degradation of crude protein and dry matter in the rumen of dairy steers. Journal of Dairy Science 65, 963-971.

Faichney, G. J. (1980). Measurement in sheep of the quantity and composition of rumen digesta and of the fractional outflow rates of digesta constituents. Australian Journal of Agricultural Research 31, $1129-1137$.

Folch, J., Lees, M. \& Sloane Stanley, G. H. (1957). Simple method for the isolation and purification of total lipids from animal tissues. Journal of Biological Chemistry 226, 497-509.

Forsberg, C. W. \& Lam, K. (1975). Use of adenosine 5-triphosphate as an indicator of the microbiota biomass in the rumen. Applied and Environmental Microbiology 33, 528-537.

Grenet, E. (1966). Les particules végétales des fécès de mouton. Annales de Zootechnie 15, 303-321.

Harfoot, C. G. (1981). Lipid metabolism in the rumen. In Lipid Metabolism in Ruminant Animals, pp. 22-55 [W. W. Christie, editor]. New York: Pergamon Press.

Henderson, C. (1973). The effects of fatty acids on pure cultures of rumen bacteria. Journal of Agricultural Science, Cambridge 81, 107-112.

INRA (1978). Tableaux de la valeur nutritive des aliments. In Alimentation des Ruminants, pp. 519-555 [R. Jarrige, editor]. Versailles: INRA Publications.

Latham, M. J. (1980). Adhesion of rumen bacteria to plant cell walls. In Microbial Adhesion to Surfaces, pp. 339-350 [R. C. W. Berkeley, J. M. Lynch, J. Melliney, R. P. Rutter and B. Vincent, editors]. Chichester: Ellis Howard.

Lefaivre, J. \& Fléchet, J. (1983). Fistulation et canule du rumen pour bovin, ovin, caprin, Cahier des Techniques de IINRA 3, 23-32.

Legay-Carmier, F. \& Bauchart, D. (1988). Extraction des bactéries de la phase solide du rumen; influence de différents traitements. Reproduction, Nutrition, Développement 28, 14I-142.

Mackie, R. I., Therion, J. J., Gilchrist, F. M. C. \& Ndhlovu, M. (1983). Processing ruminal ingesta to release bacteria attached to feed particles. South Africa Journal of Animal Science 13, 52-54.

Macleod, G. K. \& Buchanan-Smith, J. G. (1972). Digestibility of hydrogenated tallow, saturated fatty acids and soybean oil-supplemented diets by sheep. Journal of Animal Science 35, 890-895

McLoughlin, A. J. (1983). Substrate-to-biomass ratio as a process control parameter in heterogeneous populations growing on complex substrates. Biotechnology and Bioengineering 25, 2905-2919.

Maczulack, A. E., Dehority, B. A. \& Palmquist, D. L. (1981). Effects of long-chain fatty acids on growth of rumen bacteria. Applied and Environmental Microbiology 42, 856862.

Mann, H. B. \& Whitney, D. R. (1947). On a test of whether one of two random variables is stochastically larger than the other. Annals of Mathematics and Statistics 18, 50-60.

Mason, V. C. \& Bech-Andersen, S. (1975). The estimation of 2,6-diaminopimelic acid in digesta and faeces using acid ninhydrin reagent. Zeitschrift für Tierphysiologie, Tierernährung und Futtermittelkunde 36, 224229.

Merry, R. J. \& McAllan, A. B. (1983). A comparison of the chemical composition of mixed bacteria harvested from the liquid and solid fractions of rumen digesta. British Journal of Nutrition 50, 701-709.

Minato, H., Endo, A., Higuchi, M., Comoto, Y. \& Vemura, T. (1966). Ecological treatise on the rumen fermentation. I. The fractionation of bacteria attached to the rumen digesta solids. Journal of General Applied Microbiology 12, 39-52.

Minato, H. \& Suto, T. (1978). Technique for fractionation of bacteria in rumen microbial ecosystem. II. Attachment of bacteria isolated from bovine rumen to cellulose powder in vitro and elution of bacteria attached therefrom. Journal of General Applied Microbiology 24, 1-16.

Orskov, E. R., Hine, R. S. \& Grubb, D. A. (1978). The effect of urea on digestion and voluntary intake by sheep of diets supplemented with fat. Animal Production 27, $244-245$.

Sutton, J. D., Knight, R. K., McAllan, A. B. \& Smith, R. H. (1983). Digestion and synthesis in the rumen of sheep given diets supplemented with free and protected oils. British Journal of Nutrition 49, 419-432.

Ushida, K., Lassalas, B. \& Jouany, J. P. (1985). Determination of assay parameters for RNA analysis in bacterial and duodenal samples by spectrophotometry. Influence of sample treatment and preservation. Reproduction, Nutrition, Développement 25, 1037-1046.

Vermorel, M. (1978). Feed evaluation for ruminants. II. The new energy systems proposed in France. Livestock Production Science 5, 347-365. 
Williams, A. G. \& Strachan, N. H. (1984). Polysaccharide degrading enzymes in microbial populations from the liquid and solid fractions of bovine rumen digesta. Canadian Journal of Animal Science 64, Suppl., 58-59.

Wolstrup, J. \& Jensen, K. (1978). Adenosine triphosphate and deoxyribonucleic acid in the alimentary tract of cattle fed different nitrogen sources. Journal of Applied Bacteriology 45, 49-56.

Zinn, R. A. \& Owens, F. N. (1986). A rapid procedure for purine measurement and its use for estimating net ruminal protein synthesis. Canadian Journal of Animal Science 66, 157-166. 